\title{
AN ANGIOSPERM DOMINATED HERBACEOUS COMMUNITY FROM THE EARLY - MIDDLE ALBIAN OF PRIMORYE, FAR EAST OF RUSSIA
}

\author{
LINA GOLOVNEVA ${ }^{1,},{ }^{*}$, PAVEL ALEKSEEV ${ }^{1}$, EUGENIA BUGDAEVA ${ }^{2}$, ELENA VOLYNETS ${ }^{2}$ \\ ${ }^{1}$ Komarov Botanical Institute, Russian Academy of Sciences, St. Petersburg, Russia; e-mail: lina_golovneva@mail.ru. \\ ${ }^{2}$ Federal Scientific Center of the East Asia Terrestrial Biodiversity, Far Eastern Branch, Russian Academy of Sciences, Vladivostok, Russia. \\ * corresponding author
}

Golovneva, L., Alekseev, P., Bugdaeva, E., Volynets, E. (2018): An angiosperm dominated herbaceous community from the early - middle Albian of Primorye, Far East of Russia. - Fossil Imprint, 74(1-2): 165-178, Praha. ISSN 2533-4050 (print), ISSN 2533-4069 (on-line).

\begin{abstract}
An extraordinarily well-preserved autochthonous angiosperm herbaceous community is described from the Lower Cretaceous deposits of the Frentsevka Formation, southern Primorye, Far East of Russia. The locality Bolshoy Kuvshin is situated on the coast of the Ussuri Bay on the Bolshoy Kuvshin Cape near the town of Bolshoy Kamen. The plant-bearing layer was determined to be early - middle Albian in age. The angiosperm assemblage includes six species: Achaenocarpites capitellatus Krassilov et Volynets, Ternaricarpites floribundus Krassilov et Volynets, Jixia pinnatipartita S.X.Guo et G.Sun, Asiatifolium elegans G.Sun, S.X.Guo et Shao L.ZHENG and two new undetermined species. The majority of specimens are represented by fragments of branching stems with attached leaves or fruits or by almost complete plants. Two species (Jixia pinnatipartita and Asiatifolium elegans) are also in the angiosperm assemblage from the Chengzihe Formation (eastern Heilongjiang, China). The angiosperm remains are accompanied by the fern Onychiopsis psilotoides which is represented by almost entire young plants. The plant fossils were buried during a single flooding event and remained very close to their original location. They formed a pioneer open herbaceous community, consisting of ferns and angiosperms with a predominance of the latter and adapted to colonize fresh sediments in periodically flooded areas.
\end{abstract}

Key words: early angiosperms, palaeoecology, Early Cretaceous, Albian, Far East, Russia

Received: March 13, 2018 | Accepted: April 23, 2018 | Issued: August 31, 2018

\section{Introduction}

Despite the rapid progress in angiosperm palaeobotany during recent decades, the ecology and life habits of early angiosperms are still poorly documented. There are several hypotheses concerning early angiosperm ecology and environments.

According to the traditional view, early angiosperms were similar to primitive woody magnoliids with evergreen leaves and large bisexual flowers and they inhabited wet forest understory (Takhtajan 1969, Thorne 1976).

Arelated view, based on new phylogenetic reconstructions and data on the morphology and ecophysiology of the most primitive extant plants, reconstructed early angiosperms as woody plants, similar to Amborella, which grew in wet, disturbed forest understory habitats or shady streamside settings (Field et al. 2004).

Others authors suggested that the early angiosperms were weedy xeric shrubs or riparian weeds that lived in open, disturbed habitats in semiarid areas or in disturbed streamside habitats in mesic environments (Stebbins 1965,
Hickey and Doyle 1977). These hypotheses were based on arguments that variable conditions might have favored the evolution of the reproductive and vegetative features of angiosperms. This is supported by the findings of the first angiosperms in what were semiarid tropical and subtropical environments.

The palaeoherb hypothesis was based on the results of early phylogenetic analyses which placed angiosperms among Nymphaeales, Piperaceae, Saururaceae, Aristolochiaceae, and Chloranthaceae (Taylor and Hickey 1996). It inferred that the earliest angiosperms were ruderal, fast-growing herbs or shrubs, growing on sunny, unstable streamsides.

Sun and co-authors suggested an aquatic origin for angiosperms based of the life habits of Archaefructus and Sinocarpus (Sun et al. 2002, 2008). Freshwater plants are among the first angiosperms reported from the fossil record. Aquatic angiosperms are also included in the ANITA grade which is considered to be basal to angiosperms together with Ceratophyllaceae, Chloranthaceae, and magnoliids (Friis et al. 2011). 
Unfortunately, most parts of these hypotheses are based on habits, morphology, and ecology of modern species and usually cannot be verified with fossil data.

Here we report on new finds from the Albian deposits of Primorye, Far East of Russia, which allows reconstruction of the ancient angiosperm dominated herbaceous communities and their role in the Early Cretaceous vegetation. The fossil plants were buried in almost autochthonous conditions during a single flooding event and remained very close to their original location. The locality of Bolshoy Kuvshin yielded numerous fern and herbaceous angiosperm remains with the latter prevailing. The quality of the material is exceptional and almost complete plants were often found.

This locality differs considerably from many other early angiosperm localities in Primorye and worldwide which usually contain an allochthonous combination of different Early Cretaceous plants with an insignificant admixture of small shrubby or herbaceous angiosperm. It yielded herbaceous fossils that are usually not preserved because of their delicate nature. The most autochthonous or parautochthonous localities with large numbers of herbaceous angiosperms usually reflect an aquatic environment and occur significantly later in the geological record (Wang and Dilcher 2006, Cúneo et al. 2014). Autochthonous localities with a predominance of herbaceous terrestrial angiosperms are not known in the Lower Cretaceous and, as far as we know, neither in younger strata.

The fossils from Bolshoy Kuvshin have the potential to provide new data on the habits and environment of early angiosperms, important for understanding their initial radiation and also for investigation of vegetation structure and plant interactions in the Early Cretaceous.

In this paper we present a preliminary general description of the floristic composition and taphonomy of the locality Bolshoy Kuvshin and discuss in detail its stratigraphical position and age.

\section{Material and methods}

The locality Bolshoy Kuvshin is situated on the coast of the Ussuri Bay on the Bolshoy Kuvshin Cape in the Bolshoy Kamen Inlet near the town of Bolshoy Kamen in Primorye region, Far East of Russia (Text-figs 1, 2).

It was discovered by the geologist $\mathrm{A}$. Oleynikov and then studied by palaeobotanists V. Krassilov and E. Volynets (Krassilov and Volynets 2008), who described two new species of tiny herbaceous angiosperms from there: Achaenocarpites capitellatus KRASSILOV et VolynETS and Ternaricarpites floribundus KRASSILOV et VOLYNETS.

Fossils come from an outcrop of black shales and greenish gray tuffaceous sandstones exposed along the railroad in the base part of the Bolshoy Kuvshin Cape (Textfig. 3a). A detailed description is given in the stratigraphy section. The sequence commences and ends with thick layers of conglomerates. Specimens were found in a layer of fine-grained sandstone about $15 \mathrm{~cm}$ thick which is located $14 \mathrm{~m}$ above the lower conglomerate layer (Text-fig. 3b). The coordinates of the site are $43^{\circ} 07.853^{\prime} \mathrm{N}$ and $132^{\circ} 20.089^{\prime} \mathrm{E}$.

The fossiliferous sandstone is massive, without pronounced bedding planes. The grain size of the sandstone changes significantly, but gradually, throughout the layer.

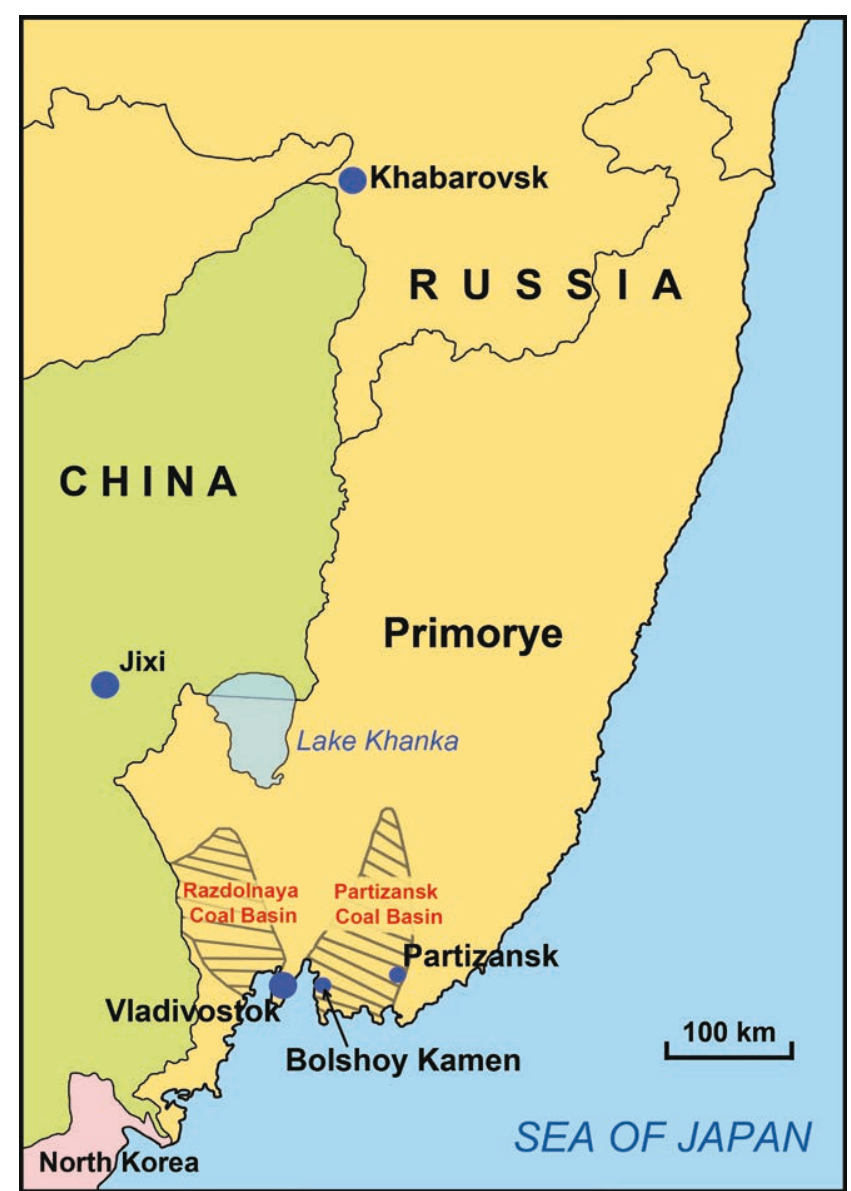

Text-fig. 1. Map of Primorye region with early angiosperm localities near Bolshoy Kamen, Partizansk and Jixi.

This layer is underlain and overlain by finely laminated stratified sandstones. The plant remains were buried in the bedding planes, as well as folded or imbedded obliquely in the sediment, crossing the bedding planes. It is likely that this fossil-bearing layer was formed during one catastrophic flooding event.

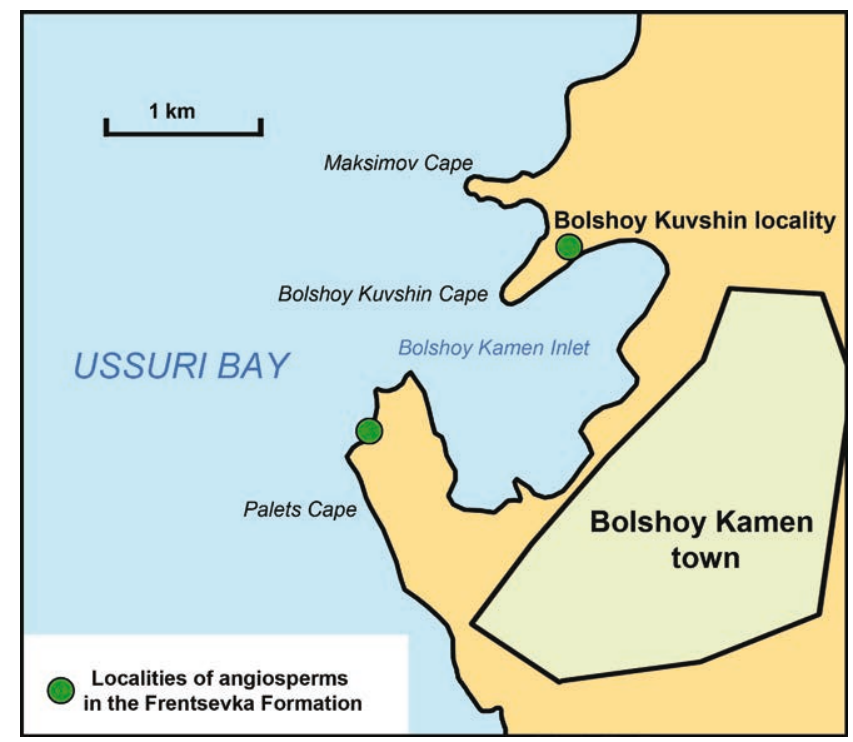

Text-fig. 2. Localities of early angiosperms near Bolshoy Kamen town. 


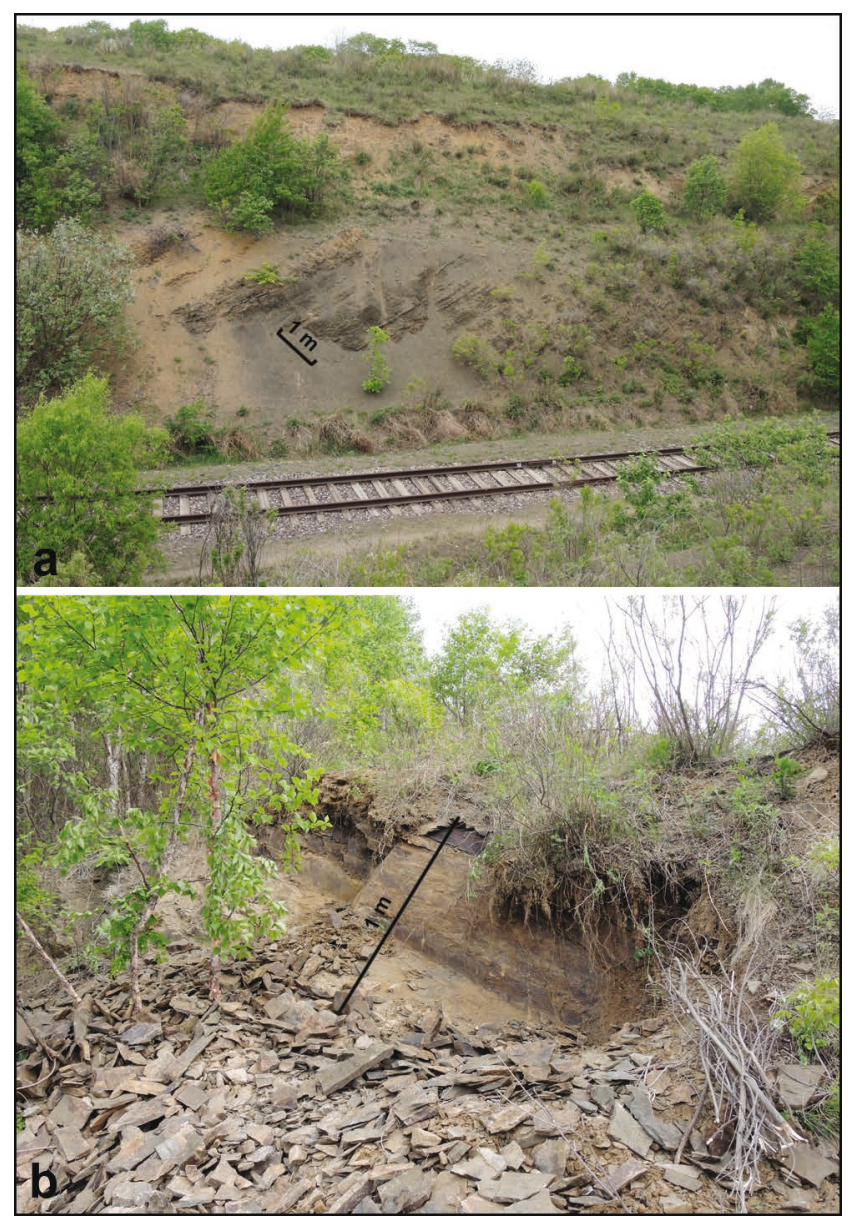

Text-fig. 3. a - section of the Frentzevka Formation along the railroad near the Bolshoy Kuvshin Cape; b - the Bolshoy Kuvshin locality.

A new excavation at this locality was made in summer 2017 by L. Golovneva, P. Alekseev, E. Bugdaeva and E. Volynets. The fossiliferous layer was uncovered in a square of about $3 \mathrm{~m}^{2}$. About two hundred specimens were collected. All specimens are deposited in the palaeobotanical collection of the Federal Scientific Center of the East Asia Terrestrial Biodiversity FEB RAS in Vladivostok (former Institute of
Biology and Soil Science), and are given the prefix IBSS 320-.

The plant fossils are preserved as brownish or dark gray impressions, yielding no structurally preserved material. Sometimes it is possible to recognize almost whole plants, with rhizomes, branching stems, leaves and fruits in organic connection. Although the preservation does not allow any study of anatomical details, these fossils provide important information on the overall habit and ecology of early angiosperms.

The material was studied under a Zeiss Stemi 2000-C binocular microscope, and photographed using a digital Nikon Coolpix P7700 camera at low-angle illumination or in water.

In this paper we assign the exposure on the Bolshoy Kuvshin Cape to the upper part of the Frentsevka Formation of the Partizansk coal basin. But the stratigraphical subdivision of the Lower Cretaceous deposits of this area is debatable. Other authors considered this sequence as the lower part of the Kangauz Formation (Markevich et al. 2000, Volynets 2005).

\section{Stratigraphy}

Non-marine Cretaceous sediments with subordinate marine or brackish deposits are widely distributed in Primorye. There are two big coal basins in the southern part of this region: the Partizansk (previously Suchan) coal basin and the Razdolnaya (previously Suifun) coal basin (Text-fig. 1). The Partizansk basin is situated along the Partizanskaya (previously Suchan) River valley, extending from the eastern coast of the Ussuri Bay to the upper reaches of the Ussuri River at a distance of about $120 \mathrm{~km}$. The main industrial deposits are located in the eastern part of the basin, near Partizansk city. Here the Lower Cretaceous deposits have been studied most intensively.

The stratigraphy of the Lower Cretaceous strata in the Partizansk basin was studied by Kryshtofovich (Kryshtofovich 1929, Kryshtofovich and Prynada 1932), Perepechina (1960), Sharudo (1960), Vereshchagin (1977), Shtempel' (1960), Krassilov (1967), Konovalov (Markevich

Table 1. The stratigraphy of the Lower Cretaceous deposits in the Partizansk coal basin.

\begin{tabular}{|c|c|c|c|c|}
\hline \multirow{2}{*}{\multicolumn{2}{|c|}{ Stage }} & \multicolumn{3}{|c|}{ Partizansk coal basin } \\
\hline & & \multirow{3}{*}{ 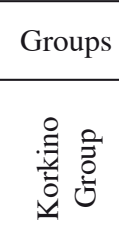 } & \multirow{2}{*}{\begin{tabular}{|l|}
\multicolumn{1}{|c|}{$\begin{array}{l}\text { Western part } \\
\text { (eastern coast of the Ussuri Bay) }\end{array}$} \\
Romanovka Fm
\end{tabular}} & \multirow{2}{*}{$\begin{array}{l}\begin{array}{c}\text { Eastern part } \\
\text { (near Partizansk city) }\end{array} \\
\text { Romanovka Fm }\end{array}$} \\
\hline Cenomanian & lower & & & \\
\hline \multirow{3}{*}{ Albian } & upper & & Kangauz Fm & Kangauz Fm \\
\hline & middle & \multirow{6}{*}{ 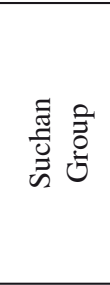 } & Unit of black siltstones & \\
\hline & lower & & Unit of heterogranular sandstones & Frentsevka Fm \\
\hline \multirow{3}{*}{ Aptian } & upper & & Coal-bearing unit & Severosuchan Fm \\
\hline & middle & & & \\
\hline & lower & & & Starosuchan Fm \\
\hline \multicolumn{2}{|l|}{ Barremian } & & & \\
\hline \multicolumn{2}{|l|}{ Hauterivian } & & & \\
\hline \multicolumn{2}{|l|}{ Valanginian } & & & Klyuchi Fm \\
\hline
\end{tabular}




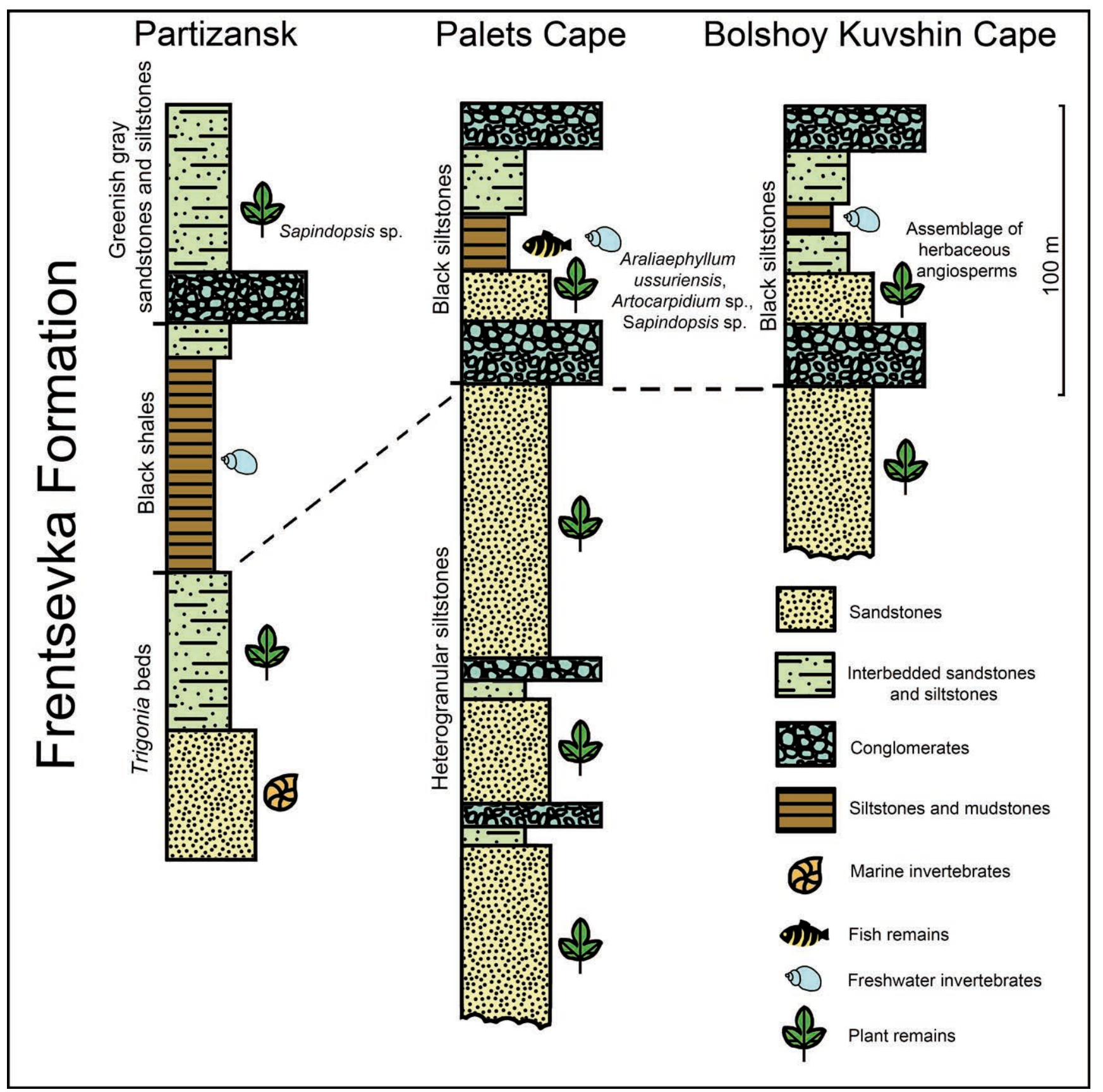

Text-fig. 4. Schematic sections of the Frentsevka Formation in different areas.

et al. 2000), Oleynikov (Oleynikov et al. 1990), Likht (1961) and Markevich (1995).

The coal-bearing deposits are together known as the Suchan Group, 1,300-1,700 m thick. It lies with erosion and angular unconformity on the Proterozoic gabbroic rocks or on the Klyuchi Formation (Tab. 1). This formation records shallow-marine to nonmarine environments with buchiid bivalves and plants of the Valanginian age (Markevich et al. 2000). The overlying variegated or red-colored volcaniclastic deposits make up the Korkino Group (up to 1,500 m), which is divided into the Kangauz (mostly sandstones) and the Romanovka (mostly siltstones) formations. This sequence records the initial phase of the Sikhote-Alin orogenic events.

The coal-bearing deposits of the Suchan Group yielded numerous fossil plants which were studied by Krassilov (1967). There are several alternative versions of the stratigraphic subdivision of the coal-bearing strata of the Partizansk coal basin. Here we use the scheme proposed by Likht $(1961,1994)$ and Krassilov (1967). According to these authors the Suchan Group consists of the Starosuchan (Neocomian), Severosuchan (Aptian) and Frentsevka (Albian) formations.

The upper boundary of the Severosuchan Formation is marked by the last thick coal layer known as the Velikan (Giant). The oldest occurrences of angiosperm come from the bottom of this layer where several Araliaephyllum luciferum (KRYsht.) Golovn. leaves were found (Kryshtofovich 1929, Golovneva 2018).

The Frentsevka Formation includes marine Trigonia beds, nonmarine black shales and a measure of greenish gray plant-bearing sandstones and siltstones (Text-fig. 4). Trigonia beds usually begin from a bedset (about 30 
m) of fine-grained grey or greenish-grey heterogranular sandstones with the remains of trigoniids (Quadratotrigonia (Transitrigonia) fudsinensis MIROL., Pterotrigonia hokkaidoana (Yен.), P. pocilliformis (Yок.), Ussuritrigonia subpyriformis KonOv.), following by beach deposits with fragments of Isognomon sp., Lima sp., Ostrea sp., and Callista pseudoplana YABE et NAGAO, representing deposits of a short-term marine ingression. The age of this assemblage was estimated as middle Albian (Markevich et al. 2000). It is overlain by fine-grained sandstones and siltstones with an admixture of conglomerates and rare thin coal layers. The thickness of this bedset is $70-80 \mathrm{~m}$. These sediments include fossil plants Onychiopsis psilotoides (STOKES et WebB) Ward, Coniopteris burejensis (ZaLessky) SEWARd, Cladophlebis frigida (HeEr) SEWARD, C. novopokrovskii Prynada, Polypodites polysorus Pryn., Elatides asiatica (Yokoyama) Krassilov and Athrotaxopsis expansa FonTAINE (Krassilov 1967). The overall thickness varies between 85 to $250 \mathrm{~m}$. The Albian age of this measure was confirmed by the occurrence of Inoceramus concentricus PARK in the south part of the Partizansk coal basin from the Vladimirskaya Unit (Oleynikov et al. 1998) which are considered as deposits from the same transgression (Markevich et al. 2000).

The black shales measure is $100-150 \mathrm{~m}$ thick and consists of interbedded siltstones and mudstones with beds of finegrained sandstones, representing mostly lacustrine deposits. These sediments yields freshwater molluscs Limnocyrena anderssoni (GRAB.), Campeloma yihsiensis GraB., $C$. tani Grab., Viviparus cf. matumotoi Suz., ostracodes and conchostracans.

The overlaying measure is $60-150 \mathrm{~m}$ thick and consists of intercalations of greenish-gray tuffaceous sandstones and siltstones with an admixture of coarse-grained sandstones and conglomerates. It yielded fossil plants Onychiopsis psilotoides, Coniopteris burejensis Podozamites sp., Elatides asiatica, E. ex gr. curvifolia (DUNKER) NATH., Elatocladus sp. and others, including remains of angiosperms, represented by small Sapindopsis leaves. This sequence begins with conglomerates (about 1.5-45 $\mathrm{m}$ in thickness) which were interpreted as marking a regional erosion event (Markevich et al. 2000).

These deposits are conformably overlain by the volcaniclastic Korkino Group. This tuffaceous sequence contains very few fossil plants (Volynets 2005) and its age is inferred as late Albian - early Cenomanian mostly on the basis of its stratigraphical position.

Marine deposits with Trigonia are distributed only in the eastern part of the Partizansk coal basin. For this reason some authors did not consider the Frentsevka Formation as a separate stratigraphical unit. The Trigonia beds and nonmarine black shales were assigned to the upper subformation of the Severosuchan Formation, and the greenish gray plant-bearing sandstones were assigned to the Kangauz Formation of the Korkino Group (Perepechina et al. 1958, Sharudo 1960, Markevich et al. 2000).

However, Krassilov (1967) noted that the characteristics of the terrigenous sediments and composition of plant fossils in the Trigonia beds and measure of greenish gray plantbearing sandstones and siltstones are similar, and interpreted the conglomerates as marking only local disconformities. In this article we follow Krassilov's point of view on the size of the Frentsevka Formation. Its total thickness near Partizansk city is about $600 \mathrm{~m}$.

The western part of the Partizansk coal basin, adjacent to the Ussuri Bay shore is called the Petrovka coal area or the Petrovka depression. The Cretaceous deposits here were also assigned to the Suchan and Korkino groups, but they are less thick and they do not contain industrial coal seams. The stratigraphical scheme of the Cretaceous deposits of this area was developed by Perepechina (1960). The deposits of the Suchan Group are divided into two formations: coalbearing and overlaying coal-free formations. The latter was correlated with the Frentsevka Formation (Krassilov 1967) and was divided into two units: heterogranular sandstones and black siltstones (Tab. 1, Text-fig. 4). A significant section of these units is exposed along the southwestern shore of the Cape Palets, near the town of Bolshoy Kamen.

The heterogranular sandstone unit is $300 \mathrm{~m}$ thick and is composed mainly of medium- and coarse-grained sandstones with numerous layers of fine-grained sandstones and siltstones, as well as layers of gravelites and conglomerates. There are occasional layers of coal-bearing sediments. This unit yielded Coniopteris sp., Vargolopteris rossica PRYN., Ruffordia goeppertii (DUNKER) SEWARD, Lobifolia novopokrovskii (PRYN.) RASSK. et LEBEDEV, Elatides asiatica (Yokoyama) Krassilov, E. ex gr. curvifolia (Dunker) Nath. and Athrotaxopsis expansa FonTAINE.
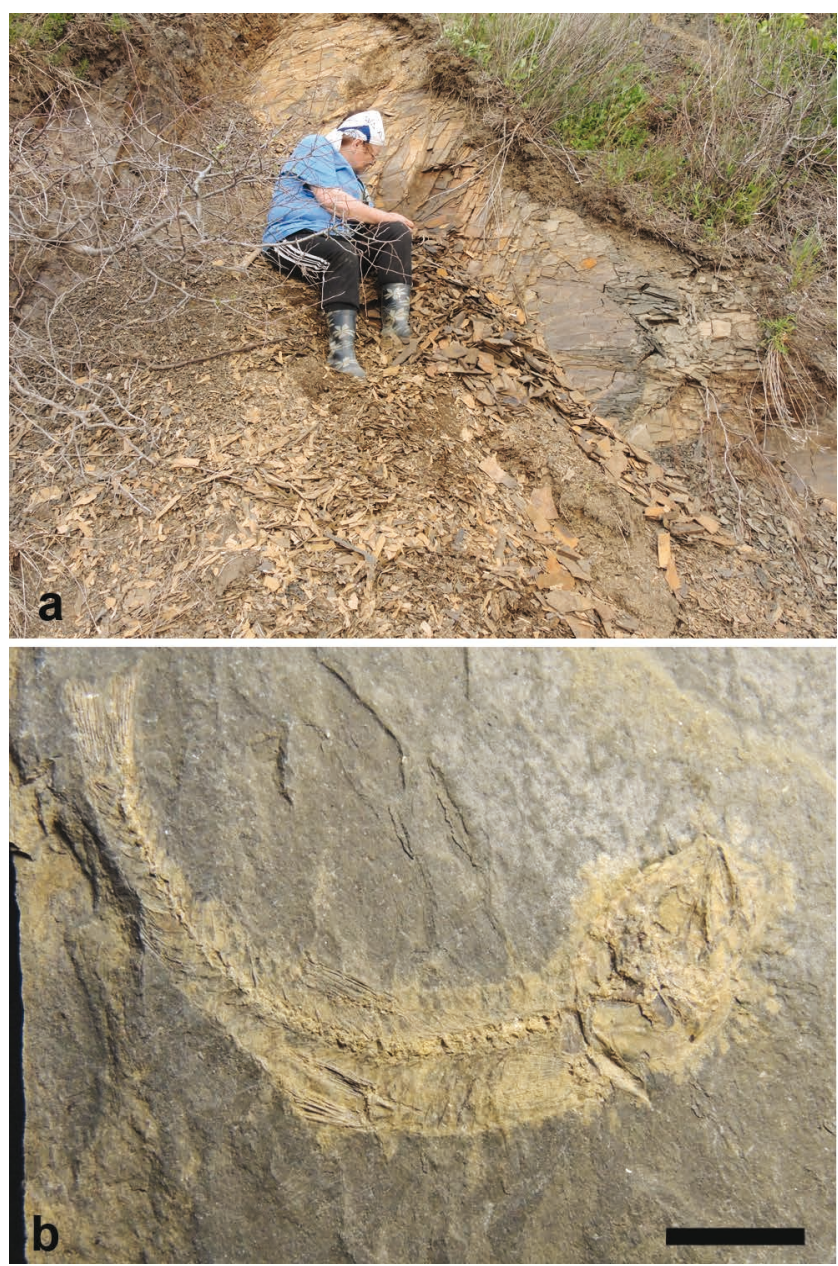

Text-fig. 5. a - unit of black siltstones from the Frentsevka Formation; b - small fish, scale bar $0.5 \mathrm{~cm}$. 
The unit composed of black siltstones is about 100 $\mathrm{m}$ thick. It begins and ends with conglomerates 10-30 m in thickness. Above and below them is interlayering of sandstones and siltstones. In the middle of this unit there are $30-40 \mathrm{~m}$ of black siltstones with numerous freshwater invertebrates and small fishes (Text-fig. 5).

Marine bivalves were not detected in this section in the Petrovka depression. The layer of black siltstones contains the same freshwater fauna as the measure of black shales near the city of Partizansk: Sphaerium, Unio, Mycetopus, Corbicula, Cyrena, Campeloma, Viviparus (Vereshchagin 1977, Markevich et al. 2000).

The numerous plant fossils occur in all part of the Frentsevka Formation. In sandstones above lower conglomerates (Text-fig. 6) Krassilov discovered angiosperms Araliaephyllum (Sassafras) ussuriensis (Krassilov) Golovn., Artocarpidium sp. and Sapindopsis sp. In addition to these also Isoetites sp., Pelletieria ussuriensis (Pryn.) Krassilov, Onychiopsis psilotoides (StOKES et WeBB) WARD, Lobifolia novopokrovskii (PRYN.) RASSK. et Lebedev, Cycadites sp., Taeniopteris sp., Elatides asiatica (Yokoyama) Krassilov, E. ex gr. curvifolia (Dunker) Nath., Athrotaxopsis expansa FonTAINE and Brachyphyllum ex gr. obesum HeER were found (Krassilov 1967).

The same section of black siltstones is exposed at the base of the Bolshoy Kuvshin Cape in the Bolshoy Kamen Inlet next to the railroad (Text-fig. 4). Krassilov (1967) collected Coniopteris burejensis (ZALESSKY) SEWARD, Onychiopsis psilotoides (STOKES et WEBB) WARD, Cladophlebis novopokrovskii PRYN., Athrotaxopsis expansa FONTAINE and Elatocladus obtusifolia OISH in sandstones from this outcrop. Later in this outcrop a new site with herbaceous angiosperms was found (Krassilov and Volynets 2008). These sediments are conformably overlain by a measure of tuffaceous sandstones, assigned by Perepechina (1960) to the Kangauz Formation.

Detailed lithological and facies description of the Early Cretaceous sediments of the Partizansk coal basin is presented in the papers by Sharudo (1960) and Golozubov (1997). Deposits of the Frentsevka Formation reflect nonmarine sedimentation and are represented by alluvial-proluvial, lacustrine, paludal and coastal facies. The accumulation of sediments occurred within the lower part of an alluvial valley, transforming it into a marine bay or estuary. Near the Palets

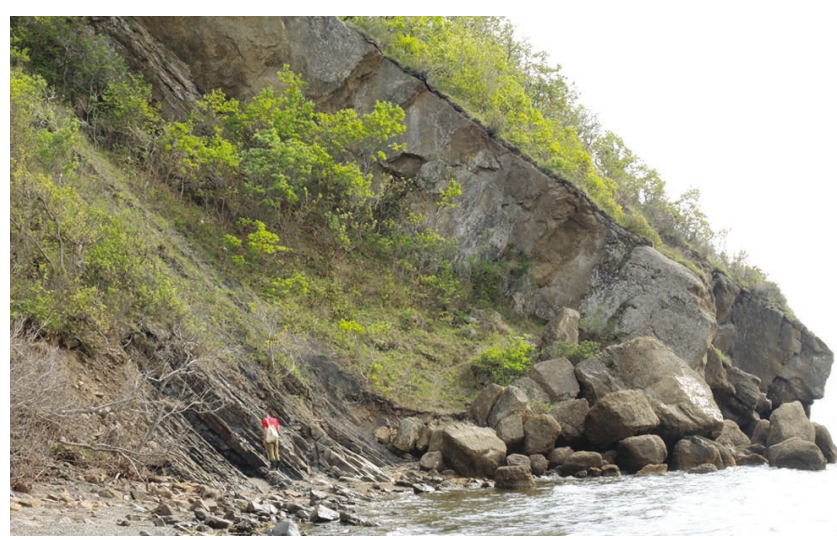

Text-fig. 6. The locality of early angiosperm near the Palets Cape.
Cape and the Bolshoy Kuvshin Cape, alluvial-lacustrine deposits are intercalated with coarse-grained sandstones and conglomerates, representing deposits of streams flowing down from the upland, located above the position of Ussuri Bay and the Muravyov-Amursky Peninsula. The Korkino Group is represented mainly by alluvial facies.

\section{Plant assemblage}

During excavation of the fossiliferous layer in the Bolshoy Kuvshin locality in 2017 about two hundred plant fossils were found. Among them remains of angiosperms predominate (about $90 \%$ ). The majority of specimens are represented by fragments of branching stems with attached leaves or fruits that belonged to small herbaceous plants. Several almost complete plants were also found (Textfigs 7-9).

The angiosperm assemblage includes six species: Achaenocarpites capitellatus KRASSILOV et VOLYNETS and Ternaricarpites floribundus KRASSILOv et Volynets, Jixia pinnatipartita S.X.Guo et G.Sun, Asiatifolium elegans G.Sun, S.X.Guo et SHAO L.ZHENG and two new species.

Among the angiosperms, remains of Achaenocarpites capitellatus occur most often. This species was described by Krassilov and Volynets (2008) based on fragmented material. The most complete specimen of Achaenocarpites is represented by a whole plant about $10 \mathrm{~cm}$ high with a straight thin branching stem, several whorls of leaves and three terminal heads, consisting of numerous achenes (Text-fig. 7a). The leaves are stipulate, ternate, and pinnatisect. Krassilov compared this species with different representatives of Ranunculales.

The second most abundant species is Asiatifolium elegans (Text-figs 7f, 8b, c). Usually this species is represented by the upper parts of stems with several helically attached and closely spaced leaves. The leaves are entire-margined, very diverse both in shape and size. Usually they are oblong, lanceolate or obovate, with an obtuse to rounded apex and decurrent base. Venation is pinnate, brochidodromous; with 5-8 secondary veins. Fructifications, associated with these leaves, have not been detected. This species was first described from the Chengziche Formation, exposed near the city of Jixi in Northeastern China (Sun and Dilcher 2002). The systematic position of Asiatifolium is uncertain.

Remains of Ternaricarpites floribundus are also abundant. This species was described by Krassilov and Volynets (2008). The most complete specimen is represented by a slender branching axis with several fruits, consisting of two to five follicles, most commonly three (Text-fig. 9a, b). The leaves of this plant are unknown. Krassilov believed that Jixia leaves belonged to the Ternaricarpites plant (Krassilov and Volynets 2008), but a more detailed study of the material showed that in fact the leaves were not attached to the stem. On the basis of morphological characters and comparisons with other fossils, it appears that Ternaricarpites may also be related to Ranunculales, such as Achaenocarpites (Krassilov and Volynets 2008). In addition it has some similarity with Hyrcantha (Sinocarpus) decussata (LENG et E.M.FrIIS) Dilcher, G.Sun, Q.JI et H.Q.Li from the Barremian to Aptian Yixian Formation of northeastern China (Leng and 


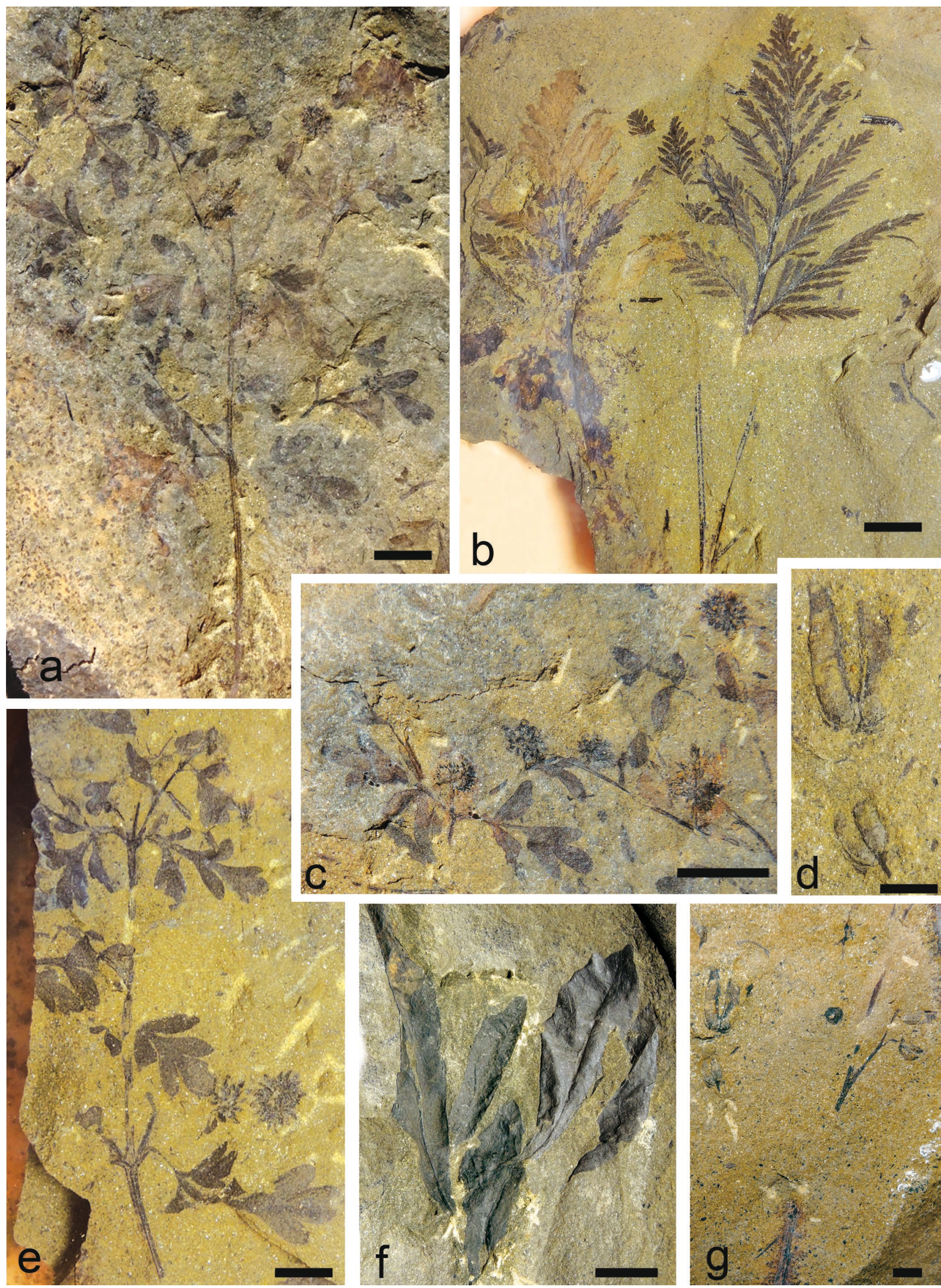

Text-fig. 7. Plant fossils from Primorye, Partizansk coal basin, Frentsevka Formation, Bolshoy Kuvshin locality, early - middle Albian. a, c, e - Achaenocarpites capitellatus KRASSILOv et VolyneTs: a - spec. IBSS 320-132, c - spec. IBSS 320-132, e - spec. IBSS 320-120; b - Onychiopsis psilotoides (STOKES et WEBB) WARD, spec. - IBSS 320-165; d, g - branching infructescence with several follicular fruits: d - spec. IBSS 320-145, g - IBSS 320-145; f - Asiatifolium elegans G.Sun, S.X.Guo et Shao L.Zheng, spec. IBSS 320-75. Scale bar 0.5 cm. 
Friis 2003, 2006, Dilcher et al. 2007). The Chinese plant has similar slender branching stems with terminal fruits consisting of two - four carpels.

Jixia pinnatipartita has simple deeply pinnately lobed entire-margined leaves (Text-fig. 9c). The lobes are thin, sublinear, usually with additional small lobes and widened bases, decurrent up and down along the midvein. The leaf base is truncate or with triangular incision. Venation is pinnate, craspedodromous. Remains of this species are quite rare. As with Asiatifolium, this species was first described from the Chengziche Formation (Sun and Dilcher 2002). Fructifications, associated with this plant, and its systematics are not known.

In addition to the previous species, there are two additional finds that we considered as belonging to new species. One new species is represented by a swollen curved branching stem with an axillary bud and three rather large petiolate, suborbicular to ovate leaves up to $6 \mathrm{~cm}$ long, with entire or crenulate margin and pinnate, brochidodromous venation (Text-fig. 8a). The leaves are thin and often folded, which indicate an aquatic or semiaquatic habit. This plant closely resembles well-preserved nymphaeaceous Pluricarpellatia peltata B.Mohr, Bernardes-De-Oliveira et D.W.TAYlor, described from the Aptian - lower Albian Crato Formation in Brazil (Mohr et al. 2008).

The other new species is represented by a branching infructescence with several follicular fruits, consisting of two-three carpels (Text-fig. 7d, g). This plant resembles Ternaricarpites, but its carpels are bigger, usually in pairs and basally fused.

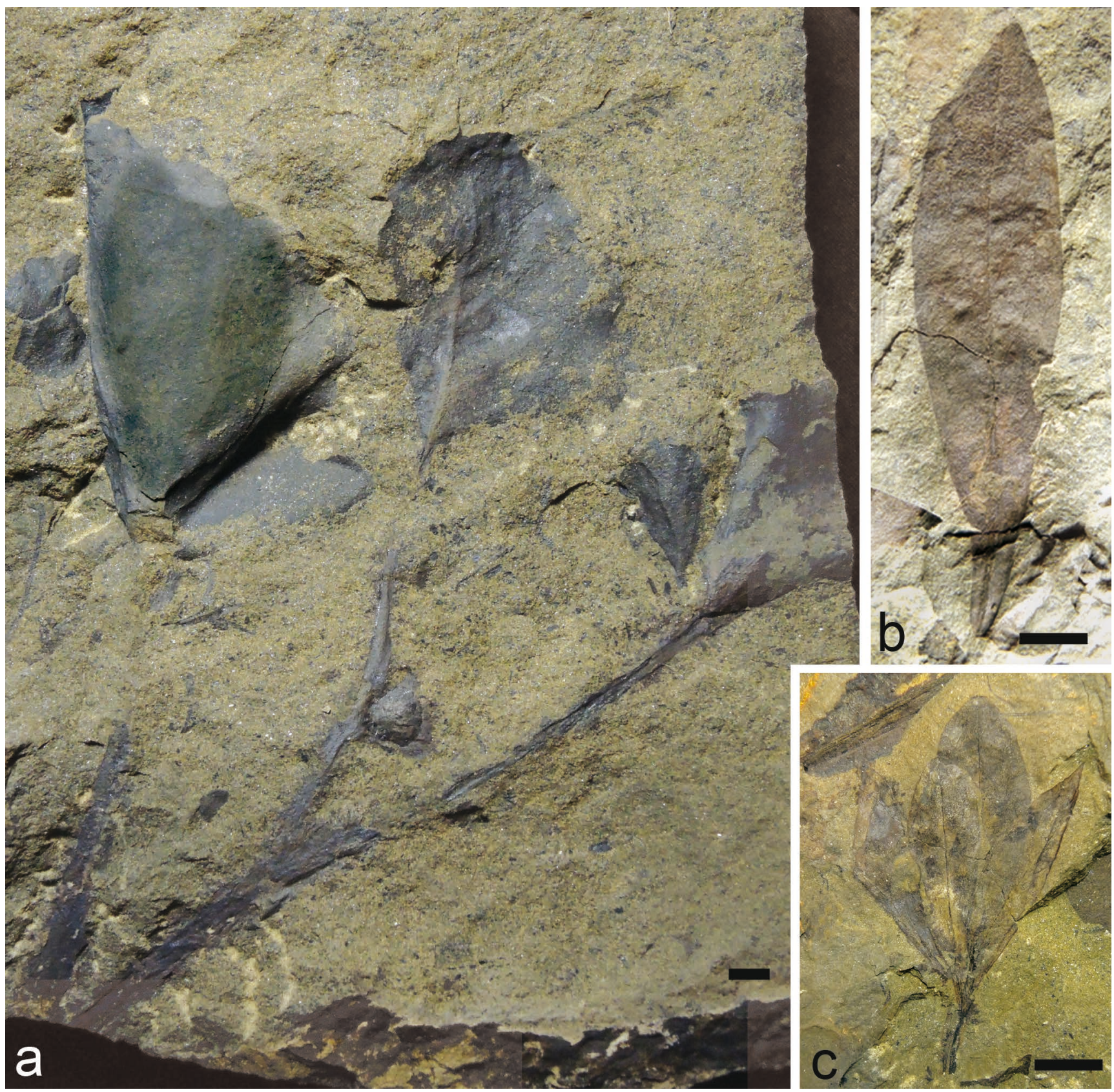

Text-fig. 8. Plant fossils from Primorye, Partizansk coal basin, Frentsevka Formation, Bolshoy Kuvshin locality, early - middle Albian. a - undetermined species, spec. IBSS 320-137; b, c - Asiatifolium elegans G.Sun, S.X.Guo et SHAO L.ZHENG: b - spec. IBSS 320-86, c - spec. IBSS 320-8. Scale bar $0.5 \mathrm{~cm}$. 


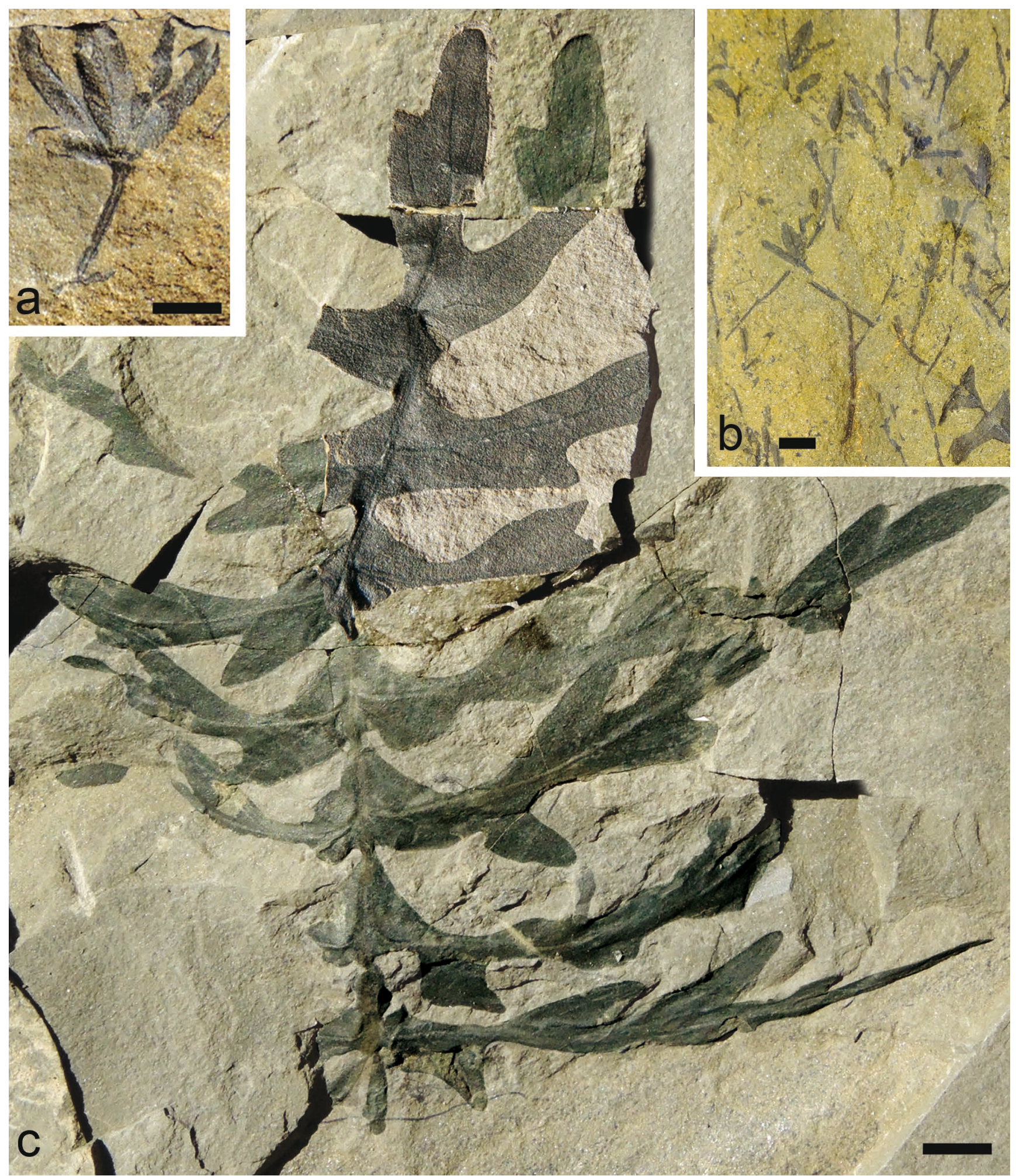

Text-fig. 9. Plant fossils from Primorye, Partizansk coal basin, Frentsevka Formation, Bolshoy Kuvshin locality, early - middle Albian. a, b - Ternaricarpites floribundus KrasSILOv et VolYNETS: a - spec. IBSS 320-10, b - spec. IBSS 320-31; c-Jixia pinnatipartita S.X.Guo et G.Sun, spec. IBSS 320-57. Scale bar $0.5 \mathrm{~cm}$.

The angiosperm remains are accompanied by relatively abundant fern remains (about $10 \%$ of specimens) and occasional Equisetum rhizomes and scale-leaved conifer shoots. The conifer component consists of fragmentary twigs (about $2-5 \mathrm{~cm}$ ) of Athrotaxopsis expansa FonTAINE and small Sequoia-like shoots. Ferns are represented mostly by Onychiopsis psilotoides (Stokes et WebB) Ward. The remains of other ferns are very fragmented. Among them Ruffordia goeppertii (Dunker) Seward, Teilhardia tenella (Pryn.) Krassilov and Coniopteris sp. can be recognized. All these species are represented only by small pieces of fronds, no more than a few pinnules.

Leaves of Onychiopsis psilotoides, on the contrary, are usually almost complete. One specimen is represented by 
whole plants, with leaves situated in several different planes in the sediment (Text-fig. 7b). Onychiopsis was widely distributed in the Early Cretaceous floras of Laurasia. This fern has leathery pinnules and xeromorphic sporangia, enclosed in an indehiscent envelope. Both features indicate water stress in the environment which corresponds to dwelling in open, sometimes brackish habitats (Friis and Pedersen 1990). Onychiopsis psilotoides is one of the most characteristic ferns in all strata of the Partizansk coal basin, which are mostly nonmarine. Perhaps, this species could also be a stream-side dweller.

Specimens of Onychiopsis from the Bolshoy Kuvshin locality differ from specimens of this fern from other sections in its smaller size. The length of the whole frond (without stalk) varies from $7 \mathrm{~cm}$ up to $30 \mathrm{~cm}$, usually being about $10-12 \mathrm{~cm}$. Leaves from other sites in the Partizansk basin usually reach $70-90 \mathrm{~cm}$ in length. This implies that in the Bolshoy Kuvshin predominantly young plants were buried.

\section{Discussion}

The age of the Frentsevka Formation was based mainly on marine molluscs from Trigonia beds. Konovalov estimated the age to be middle Albian (Markevich et al. 2000). But in reality the bivalve assemblage includes many endemic species. Other species with a wider distribution (Pterotrigonia hokkaidoana, P. pocilliformis, Inoceramus concentricus) have a rather wide stratigraphical range during the Albian (Tashiro and Matsuda 1983, Matsukawa et al. 1997).

Freshwater molluscs, ostracodes and conchostracans from black shales are in general insufficiently studied. At present they suggest an age range from the Aptian to the Albian (Markevich et al. 2000).

But these deposits contain a rich plant assemblage including ferns, gingoaleans, cycadophytes, czekanowskialeans, conifers and angiosperms. Krassilov (1967) noted that plant assemblages from all formations of the Partizansk coal basin have a similar composition and differ mainly in the quantitative ratio between species. The most abundant species in the Frentsevka Formation are Onychiopsis psilotoides (Stokes et WeBB) WARD, Cladophlebis frigida (Heer) Seward, Elatides asiatica (Yokoyama) Krassilov, Athrotaxopsis expansa FonTAINE, Coniopteris burejensis (Zalessky) Seward, Cladophlebis frigida (Heer) Seward, Lobifolia novopokrovskii (PrYn.) RAsSK. et LEBEDEV, Polypodites polysorus Pryn. Elatides asiatica (Yокоунмa) Krassilov, Elatocladus ex gr. curvifolia (DunKer) Nath. and Athrotaxopsis expansa FontAINE. All these species have a wide distribution in the Early Cretaceous.

Volynets $(2005,2006)$ developed a very detailed stratigraphical sequence of the floristic assemblages for the Partizansk, Razdolnaya and Alchan coal basins. She distinguished two successive assemblages dated from middle to late Albian in the deposits of the Frentsevka Formation. Unfortunately these assemblages were not compared with any accurately dated assemblages in other regions. Therefore they are not of use for age determination of the Bolshoy Kuvshin locality.
Plants having the greatest biostratigraphic significance are early angiosperms. In the mid-Cretaceous angiosperms were already quite numerous and the majority of species were characterized by a narrow stratigraphical range. Unfortunately, many species were endemic which thus prevents any correlation with different basins.

In addition to herbaceous plants from the Bolshoy Kuvshin locality, three species of angiosperms were recorded from the Frentsevka Formation: Araliaephyllum (Sassafras) ussuriensis (Krassilov) Golovn., Artocarpidium sp., Sapindopsis cf. angusta (Heer) Seward et V.Conway.

In the extensively studied sequence of the Potomac Group in the eastern United States, Araliaephyllum and Sapindopsis were recorded in the deposits referred to the lower part of the pollen Zone II-B (locality Bank near Brook). The age of this locality was determined as early to middle Albian (Doyle and Hickey 1976) or as middle to late Albian (Hochuli et al. 2006, Doyle and Upchurch 2014). In Zone I (Aptian to earliest Albian) only simple unlobed leaves with predominantly pinnate venation were recovered. From Zone II-C (latest Albian-Cenomanian) large platanoid leaves became abundant in channel and levee facies (Doyle and Upchurch 2014). In accordance with these data, the age of the Frentsevka Formation should be estimated as middle Albian, possibly including the beginning of late Albian.

However, the Bolshoy Kuvshin assemblage includes two species, in common with the flora of the Chengzihe Formation, including in Jixi Group: Jixia pinnatipartita and Asiatifolium elegans. The angiosperms from the Chengzihe Formation were initially considered to be Hauterivian - early Barremian in age (Sun and Dilcher 2002). More recently reinvestigation of Aucellina bivalves from the Jixi group indicated a younger age, from the Barremian to Albian (Gu et al. 1997). The Chengzihe Formation is dominated by nonmarine coal-bearing deposits that intercalated with several marine beds. It contains plant megafossils, ostracodes, fishes, reptiles, abundant bivalves and dinoflagellates (Sha et al. 2003). Nowadays the Chengzihe Formation is considered to be mainly Aptian but lower marine beds perhaps extends downward into the Barremian. The overlying Muling Formation is composed of nonmarine coal-bearing deposits intercalated rarely with brackish sediments. It is dominated by grey and greenish-grey fine-grained sandstones and siltstones interbedded with mudstones, tuffs and coal beds. The fossils recovered from the Muling Formation (brackish bivalves and dinoflagellate assemblage) suggest an Aptian early Albian age (Sha et al. 2003).

Angiosperms were collected from the middle and upper part of the Chengzihe Formation and are expected to be Aptian in age. Until the present time, early angiosperms were considered as a rapidly evolving group whose species have the narrow stratigraphical ranges. The difference in age of the same species from Primorye and Heilongjiang implies that Jixia pinnatipartita and Asiatifolium elegans had wider stratigraphical ranges, maybe from Aptian to early - middle (late?) Albian, or that the age determinations were not accurate enough and additional stratigraphical investigations are necessary. Perhaps, an early Albian age could be a possibility for both plant assemblages.

Overall, we accept an early - middle Albian age for early angiosperms from the Frentsevka Formation. 


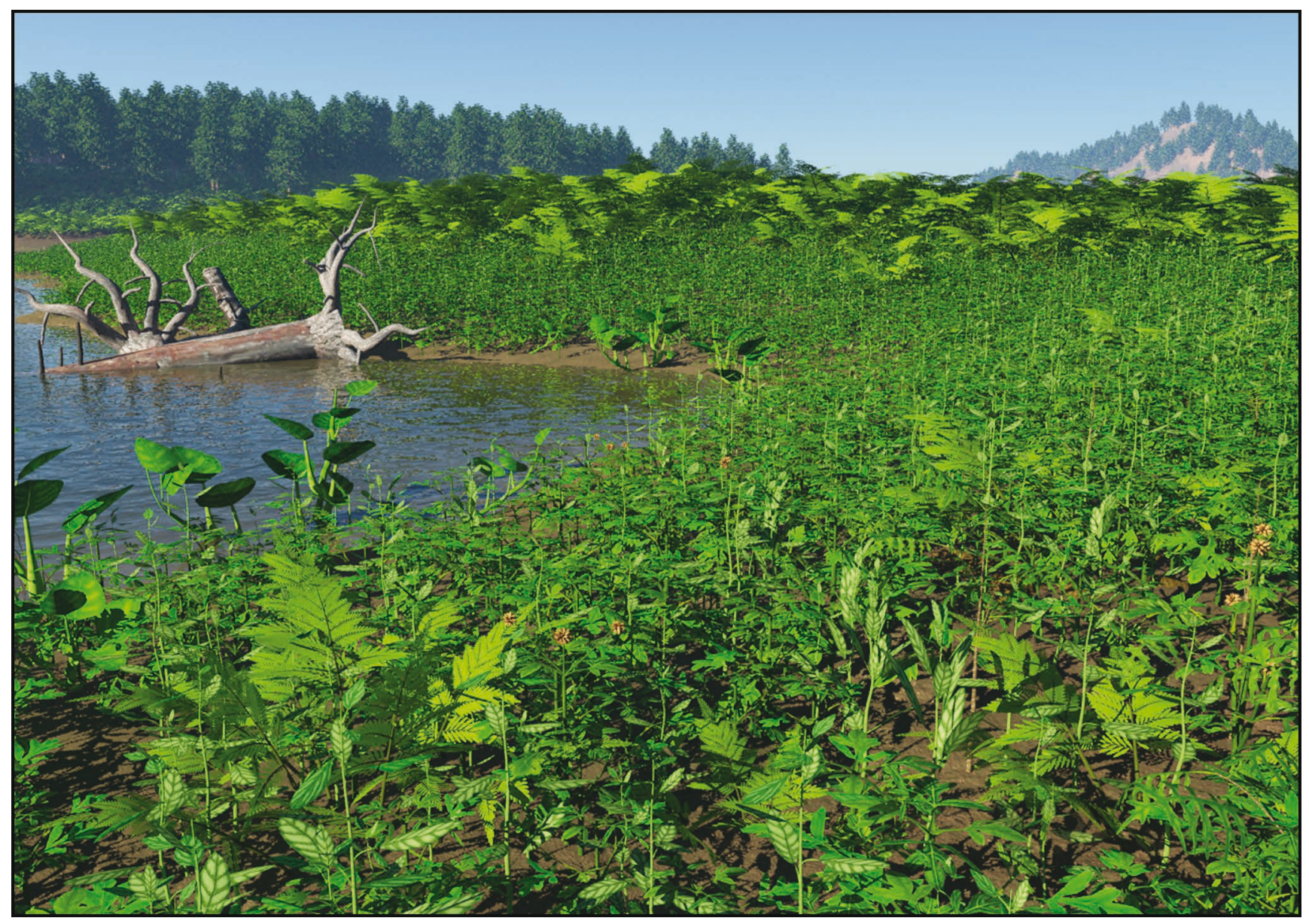

Text-fig. 10. Reconstruction of environment with herbaceous angiosperms from deposits of the Frentsevka Formation.

Deposits of the Frentsevka Formation near the Bolshoy Kuvshin Cape are represented by alluvial-lacustrine floodplain facies intercalated with coarse-grained sandstones and conglomerates, representing deposits of braided rivers flowing down from the upland where is now located the Ussuri Bay (Sharudo 1960).

The plant-bearing layer is about $15 \mathrm{~cm}$ thick and represented by fine-grained non-stratified sandstone. This layer is underlain and overlain by finely laminated sandstones and siltstones. Most likely, the latter were deposited on the floodplain as a result of the activity of small, meandering channels. The plant remains are often folded, rolled and cross bedding planes. It is likely that this fossil-bearing layer was formed during one single catastrophic flooding event. The locality contains numerous remains of diverse herbaceous angiosperms with an admixture of the fern Onychiopsis psilotoides. Many specimens are represented by almost complete plants or big fragments with attached leaves and fruits. Plants were small (10-30 cm high) and very delicate. Their complete preservation in rather coarse sediment indicates the absence of water transport. They were deposited very close to their original location. Thus, this locality can be considered as autochthonous, reflecting the vegetation which grew near to the burial place. We interpret this vegetation as an open herbaceous community, consisting of ferns and angiosperms with a predominance of the latter. This community occupied low flat plains between river channels. Conifers and other woody plants were perhaps excluded from this environment by periodic flood events, low drainage, and by the unstable groundwater level. In the plant-bearing layer conifers are represented mostly by very rare, small $(2-5 \mathrm{~cm})$ shoots of Athrotaxopsis expansa. These remains are considered as an allochthonous admixture in this locality, as well as the small rare fragments of the ferns Ruffordia goeppertii, Teilhardia tenella and Coniopteris sp. In several meters below the plant-bearing layer there is leaf mat in the sandstone, consisting exclusively of Athrotaxopsis expansa twigs and cones. Possibly this plant can have formed thickets on levees and other elevated parts of a floodplain.

The fern Onychiopsis psilotoides is represented by almost complete, but small young plants. This implies that the fern-angiosperm herbaceous community was a pioneer, reflecting the early succession stage and adapted to colonize fresh sediments in periodically flooded areas. Powerful floods, bearing abundant sediments or migration of channels can periodically destroy pioneer communities. Krassilov suggested that herbaceous angiosperms could also colonize fresh ash fallouts (Krassilov and Volynets 2008). Reconstruction of such an angiosperm herbaceous community is shown in Text-fig. 10.

The locality Bolshoy Kamen, containing abundant remains of several herbaceous angiosperm species, is significantly different from other early - middle Albian angiosperm sites, where the angiosperm can be diverse and well-preserved, but their remains occur rarely and irregularly. 
The preservation of complete herbaceous angiosperm, ferns and gnetaleans is typical for the Aptian - early Albian Crato Formation in Brazil (Mohr and Friis 2000, Mohr et al. 2015), and for the Aptian Yixian Formation in Northeast China (Sun and Dilcher 1997, Sun et al. 1998, Leng and Friis 2003, Dilcher et al. 2007, Sun et al. 2008, Yang et al. 2013).

In the Yixian Formation herbaceous plant fossils occur in finely laminated lacustrine tuffaceous siltstones together with diverse invertebrate lake fauna and fishes (Pan et al. 2013).

The Crato plattenkalk limestones were also formed by a large freshwater or brakish-water lake. It was suggested that periodic torrent rainfall could have washed down into the water almost complete plants which grew not far from the lake shore (Mohr et al. 2015). Angiosperms constituted a minor scattered element of the nearshore vegetation (Mohr and Friis 2000). It is interesting that many herbaceous remains from the Crato Formation are represented by young plants, documenting their early growth stages (Rydin et al. 2003). It is possible that these plants also could have inhabited periodically disturbed places along streams or lake edge.

An authochthonous plant assemblage from the riparian deposits was described from the Bajo Grande locality, coming from the lower Aptian Anfiteatro de Tico Formation, Argentina (Cladera et al. 2007). This assemblage includes the liverwort Ricciopsis gradensis Cladera et al., ferns Adiantopteris tripinnata CLADERA et al., and undetermined Schizaeaceae, and the gnetophyte Ephedra verticillata CladerA et al. Taphonomical studies suggest that these plants grew and were buried near the levee. This locality documents an open fern herbaceous vegetation with gnetaleans, but unfortunately without angiosperms.

Our data support Hickey and Doyle's (1977) interpretation of early angiosperms as riparian weeds. They also show that early angiosperm preferred open wet fern communities, inhabited periodically flooded river valleys and coastal plains. Such environments were favorable for appearance of different aquatic and semiaquatic life forms, which are so numerous among the early angiosperms.

\section{Acknowledgements}

The present study was carried out within the framework of the institutional research project (no. AAAA-A18-118030690081-1) of the Komarov Botanical Institute of the Russian Academy of Sciences and was supported by the Russian Foundation for Basic Research (project 16-04-01411). We would like to thank A. Herman and other anonymous reviewers for their helpful comments during preparation of the manuscript.

\section{References}

Cladera, G., Del Fueyo, G. M., Villar de Seoane, L., Archangelsky, A. (2007): Early Cretaceous riparian vegetation in Patagonia, Argentina. - Revista del Museo Argentino de Ciencias Naturales, n.s., 9(1): 49-58.

https://doi.org/10.22179/REVMACN.9.364
Cúneo, N. R., Gandolfo, M. A., Zamaloa, M. C., Hermsen, E. (2014): Late Cretaceous Aquatic Plant World in Patagonia, Argentina. - PLoS ONE, 9(8): e104749. https://doi.org/10.1371/journal.pone.0104749

Dilcher, D. L., Sun, G., Ji, Q., Li, H. (2007): An early infructescence Hyrcantha decussata (comb. nov.) from the Yixian Formation in northeastern China. - Proceedings of National Academy of Sciences USA, 104(22): 9370-9374. https://doi.org/10.1073/pnas.0703497104

Doyle, J. A., Hickey, L. J. (1976): Pollen and leaves from the mid-Cretaceous Potomac Group and their bearing on early angiosperm evolution. - In: Beck, C. B. (ed.), Origin and Early Evolution of Angiosperms. Columbia University Press, New York, pp. 139-206.

Doyle, J. A., Upchurch, G. R. (2014): Angiosperm clades in the Potomac Group: what have we learned since 1977? - Bulletin of the Peabody Museum of Natural History, 55(2): 111-134.

https://doi.org/10.3374/014.055.0203

Field, T. S., Arens, N. C., Doyle, J. A., Dawson, T. E., Donoghue, M. J. (2004): Dark and disturbed: a new image of early angiosperm ecology. - Paleobiology, 30: 82-107. https://doi.org/10.1666/0094-8373(2004)030<0082:DADANI $>2.0 . \mathrm{CO} ; 2$

Friis, E. M., Crane, P. R., Pedersen, K. R. (2011): Early flowers and angiosperm evolution. - Cambridge University Press, Cambridge, 585 pp. https://doi.org/10.1017/CBO9780511980206

Friis, E. M., Pedersen, K. R. (1990): Structure of the Lower Cretaceous fern Onychiopsis psilotoides from Bornholm, Denmark. - Review of Palaeobotany and Palynology, 66: 47-63. https://doi.org/10.1016/0034-6667(90)90028-H

Golovneva, L. B. (2018): Diversity of palmately lobed leaves in the early-middle Albian of eastern Russia. Cretaceous Research, 84: 18-31. https://doi.org/10.1016/j.cretres.2017.11.005

Golozubov, V. V., Dong, W. (1997): Dinamika formirovaniya melovogo Partizansko-Sukhodol'skogo epikontinental'nogo basseyna (Yuzhnoe Primorie) [Dynamics of formation of the Early Cretaceous Partizansk-Sukhodol epicontinental basin (South Primorye)]. - Russian journal of Pacific geology, 46(6): 46-57. (in Russian)

Gu, Z. W., Li, Z. S., Yu, X. H. (1997): Lower Cretaceous Bivalves from the Eastern Heilongjiang Province of China. - Science Press, Beijing, 301 pp.

Hickey, L. J., Doyle, J. A. (1977): Early Cretaceous fossil evidence for angiosperms evolution. - The Botanical Review, 43(1): 3-104. https://doi.org/10.1007/BF02860849

Hochuli, P. A., Heimhofer, U., Weissert, H. (2006): Timing of early angiosperm radiation: recalibrating the classical succession. - Journal of the Geological Society, London, 163: 587-594. https://doi.org/10.1144/0016-764905-135

Krassilov, V. A. (1967): Rannemelovaya flora yuzhnogo Primoriya i ee znachenie dlya stratigrafii [Early Cretaceous Flora of southern Primorye and its significance for the stratigraphy]. - Nauka, Moscow, 264 pp. (in Russian)

Krassilov, V., Volynets, Y. (2008): Weedy Albian angiosperms. - Acta Palaeobotanica, 48(2): 151-169. 
Kryshtofovich, A. N. (1929): Otkrytie drevneishikh dvudolnykh pokrytosemennykh i ekvivalentov potomakskikh sloev na Suchane i v Ussuriiskom krae [The discovery of the oldest dicotyledons angiosperms and equivalents of the Potomac beds on Suchan in the Ussuri region.] - Izvestiya Geologicheskogo Komiteta, 48: 113-45. (in Russian)

Kryshtofovich, A. N., Prynada, V. D. (1932): Mater'yaly $\mathrm{k}$ Mezozoyskoi flore Ussuriiskogo kraya [Materials on Mesozoic flora of the Ussuriisk krai]. - Izvestiya Vsesoyuz. Geol. Razved. Ob'ed., 2(29): 363-373. (in Russian)

Likht, F. R., (1961): Novaya nakhodka flory dvudol'nykh $\mathrm{v}$ nizhnem melu Suchana [The new finding of dicots in lower Cretaceous deposits of the Suchan coal basin]. Inform. Sbornik PGU, 2: 47-50. (in Russian)

Likht, F. R. (1994): Usloviya obrazovaniya i strtigrafiya nizhnemelovykh otlozhenii yuzhnogo Primoriya [Conditions of generation and stratigraphy of the Lower Cretaceous deposits of southern Primorye]. - Russian journal of Pacific geology, 6: 55-67. (in Russian)

Leng, Q., Friis, E. M. (2003): Sinocarpus decussatus gen. et sp. nov., a new angiosperm with basally syncarpous fruits from the Yixian Formation of Northeast China. Plant Systematics and Evolution, 241(1-2): 77-88. https://doi.org/10.1007/s00606-003-0028-8

Leng, Q., Friis, E. M. (2006): Angiosperm leaves associated with Sinocarpus infructescences from the Yixian Formation (Mid-Early Cretaceous) of NE China. - Plant Systematics and Evolution, 262(3-4): 173-187.

https://doi.org/10.1007/s00606-006-0461-6

Markevich, P. V., Konovalov, V. P., Malinovskii, A. I., Filippov, A. N. (2000): Nizhnemelovye otlozheniya Sikhote-Alinya [Lower Cretaceous Deposits of the Sikhote-Alin]. - Dal'nauka, Vladivostok, 282 pp. (in Russian)

Markevich, V. S. (1995): Melovaya palinoflora severa Vostochnoy Asii [Cretaceous palynoflora of Northeastern Asia]. - Dal'nauka, Vladivostok, 200 pp. (in Russian)

Matsukawa, M., Takahashi, O., Hayashi, K., Ito, M., Konovalov, V. P. (1997): Early Cretaceous paleogeography of Japan, based on tectonic and faunal data. - Memoirs of the Geological Society of Japan, 48: 29-42.

Mohr, B. A. R., Friis, E. M. (2000): Early angiosperms from the Lower Cretaceous Crato Formation (Brazil), a preliminary report. - International Journal of Plant Sciences, 161(6): S155-S167.

https://doi.org/10.1086/317580

Mohr, B. A. R., Bernardes-de-Oliveira, M. E. C., Taylor D. W. (2008): Pluricarpellatia, a nymphaealean angiosperm from the Lower Cretaceous of northern Gondwana (Crato Formation, Brazil). - Taxon, 57(4): 1147-1158.

Mohr, B. A. R., Bernardes-de-Oliveira, M. E. C., Loveridge, R., Pons, D., Sucerquia, P. A., Castro-Fernandes, M. C. (2015): Ruffordia goeppertii (Schizaeales, Anemiaceae) - A common fern from the Lower Cretaceous Crato Formation of northeast Brazil. - Cretaceous Research, 54: 17-26.

https://doi.org/10.1016/j.cretres.2014.11.006

Oleynikov, A. V., Kovalenko, S. V., Nevolina, S. I. (1990): Novye dannye po stratigrafii verkhnemezozoyskikh otlozheniy severnoy chasti Partizanskogo kamennoy- gol'nogo basseyna [New data on Upper Mesozoic stratigraphy in northern areas of the Partizansk coal basin]. - In: Kontinental'nyy mel SSSR. [The Continental Cretaceous in the USSR]. DVO AN SSSR, Vladivostok, pp. 114-126. (in Russian)

Oleynikov, A. V., Lushnilov, V. F., Kovalenko, S. V., Kutub-Zade, T. K. (1998): Ob'yasnitelnaya zapiska. Gosudarstvennaya geologicheskaya karta Rossiiskoi Federatsii masshtaba 1: 200000. Seriya Yuzhno-Sikhote-Alinskaya. Sheet K-53-VIII. 164 pp. (in Russian)

Pan, Y., Sha, J., Zhou, Z., Fürsich F. T. (2013): The Jehol Biota: definition and distribution of exceptionally preserved relicts of a continental Early Cretaceous ecosystem. - Cretaceous Research, 44: 30-38. https://doi.org/10.1016/j.cretres.2013.03.007

Perepechina, E. A. (1960): Petrovskiy uchastok Shitukhinskogo uglenostnogo rayona Suchanskogo kamennougol'nogo basseyna [The Petrovskiy area of Shitukhinsky coal field of the Suchan coal basin]. - Trudy Laboratorii geologii uglya AN SSSR, 10: 114-153. (in Russian)

Perepechina, E. A., Sharudo, I. I., Semerikov, A. A. (1958): Srtatigrafiya uglenostnykh i nadyglenostnykh otlozheniy Suchanskogo kamennougol'nogo basseyna [Stratigraphy of coal bearing and over coal bearing deposits of Suchan coal basin]. - Trudy Laboratorii geologii uglya AN SSSR, 8: 73-125. (in Russian)

Rydin, C., Mohr, B., Friis, E. M. (2003): Cratonia cotyledon gen. et sp. nov.: a unique Cretaceous seedling related to Welwitschia. - Proceedings of the Royal Society of London B, 270(suppl): S29-S32. https://doi.org/10.1098/rsbl.2003.0044

Sha, J., Matsukawa, M., Cai, H., Jiang, B., Ito, M., He, C., Gu, Z. (2003): The Upper Jurassic-Lower Cretaceous of eastern Heilongjiang, northeast China: stratigraphy and regional basin history. - Cretaceous Research, 24: 715-728. https://doi.org/10.1016/j.cretres.2003.07.006

Sharudo, I. I. (1960): Sostav i usloviya osadkonakopliniya uglenosnykh otlozheniy Starogo Suchana [Composition and condition of sedimentation coal bearing deposits of Old Suchan]. - Trudy Laboratorii geologii uglya AN SSSR, 10: 5-93. (in Russian)

Shtempel', B. M. (1960): Melovaya fitostratigrafiya yuzhnogo Pimoriya [Cretaceous phytostratigraphy of Southern Primorye]. - Trudy Laboratorii geologii uglya AN SSSR, 10: 167-193. (in Russian)

Stebbins, G. L. (1965): The probable growth habit of the earliest flowering plants. - Annals of the Missouri Botanical Garden, 52: 457-468. https://doi.org/10.2307/2394810

Sun, G., Dilcher, D. L. (1997): Discovery of the oldest known angiosperm inflorescences in the Lower Cretaceous of Jixi, China. - Acta Palaeontologica Sinica, 36: 135-142.

Sun, G., Dilcher, D. L. (2002): Early angiosperms from the Lower Cretaceous of Jixi, eastern Heilongjiang, China. - Review of Palaeobotany and Palynology, 121: 91-112. https://doi.org/10.1016/S0034-6667(02)00083-0

Sun, G., Dilcher, D. L., Zheng, S. (2008): A review of recent advances in the study of early angiosperms from northeastern China. - Palaeoworld, 17: 166-171. https://doi.org/10.1016/j.palwor.2008.10.002 
Sun, G., Dilcher, D. L., Zheng, S. L., Zhou, Z. K. (1998): In search of the first flower: a Jurassic Angiosperm, Archaefructus, from Northeast China. - Science, 282: 1692-1695. https://doi.org/10.1126/science.282.5394.1692

Sun, G. Ji., Q., Dilcher, D. L., Zheng, S., Nixon, K.C., Wang, X. (2002): Archaefructaceae, a new basal Angiosperm family. - Science, 296: 899-904. https://doi.org/10.1126/science.1069439

Takhtajan, A. L. (1969). Flowering plants: origin and dispersal. - Smithsonian Institution Press, Washington, 310 pp.

Taylor, D. W., Hickey, L. J. (1996): Evidence for and implications of an herbaceous origin for angiosperms. - In: Taylor, D. W., Hickey, L. J. (eds), Flowering plant origin, evolution, and phylogeny. Chapman and Hall, New York, pp. 232-266. https://doi.org/10.1007/978-0-585-23095-5_9

Tashiro, M., Matsuda, T. (1983): Stratigraphy and inhabited environments of the Cretaceous trigonians in Japan. Fossil, 34: 19-32. (in Japanese with English abstract)

Thorne, R. F. (1976): A phylogenetic classification of the Angiosperms. - Evolutionary Biology, 9: 35-106.
Vereshchagin, V. N. (1977): Melovaya sistema Dal'nego Vostoka [The Cretaceous System of the Far East]. - Nedra, Leningrad, 207 pp. (in Russian).

Volynets, E. B. (2005): The Aptian-Cenomanian Flora of Primorye, Part 1: Floral Assemblages. - Stratigraphy and Geological Correlation, 13: 613-631.

Volynets, E. B. (2006): The Aptian-Cenomanian Flora of Primorye, Part 2: Correlation of Floral Assemblages. Stratigraphy and Geological Correlation, 14: 200-210. https://doi.org/10.1134/S0869593806020079

Wang, H., Dilcher, D. L. (2006): Aquatic angiosperms from the Dakota Formation (Albian, Lower Cretaceous), Hoisington III locality, Kansas, USA. - Interntional Journal of Plant Science, 167(2): 385-401. https://doi.org/10.1086/499502

Yang, Y., Lin, L., Wang, Q. (2013): Chengia laxispicata gen. et sp. nov., a new ephedroid plant from the Early Cretaceous Yixian Formation of western Liaoning, Northeast China: evolutionary, taxonomic, and biogeographic implications. - BMC Evolutionary Biology, 13: 72 (12 pp). https://doi.org/10.1186/1471-2148-13-72 